\title{
Socialist Market Economy Principles as a Neo-Marxist Policy
}

\author{
Gürhan Uysal \\ Ondokuz Mayıs University, Samsun, Turkey
}

\begin{abstract}
Marx has two theories: surplus value and labor value. Marx defends positivist socialism. Hegel impressed Marx ideas during his $\mathrm{PhD}$. This study is based on Marx opinions. Socialist Market Economy has two principles: central planning and market economy. State implements central planning for investments, and firms operate their marketing and production activities. In socialist economy, state decides firm's marketing and production activities. That policy may decrease effectiveness in national economy.
\end{abstract}

Keywords: Karl Marx, socialism, market economy, socialist market economy, firm decisions

\section{Introduction}

Theory of Marx is labor value theory. Marx adopted that notion from David Ricardo, classical economist. Secondly, Marxist economy may be applied through socialist market economy in 21 st century, which contains market economy variables. Major theory of Karl Marx is surplus value, which is profit of firm. Dialectic Materialism is that labors become owners, and obtain the profit (Uysal, 2016b).

Marx has dialectic view. Dialectic is theses and antitheses conflict. In 1800s, thesis is capitalism, antithesis is socialism. Marx defends scientific socialism. It describes positivism and materialism. Marx considers life and context with positivist science. Thus, dialectic materialism appeared on society with positivism and scientific socialism.

\section{Literature Review: Economy of Marx}

Karl Marx has three economy policies:

- Labor value,

- Surplus value,

- Wage policy.

Labor value supposes that labors generate customer value for firms. Workforce may upload value for products. Labor value is related with "human capital" theory. That policy is called as "human capital" policy in current organizations. It is assumed that human capital increases firm performance. Therefore, workers' qualifications and motivations are important to competitiveness of firm. In addition, technology may determine value for products currently in modern economy. Therefore, workers and technology may increase customer value in firm management in modern economy.

Gürhan Uysal, Ph.D., associate professor, School of Business, Kurupelit Campus, Ondokuz Mayıs University, Samsun, Turkey.

Correspondence concerning this article should be addressed to Gürhan Uysal, School of Business, Ondokuz May1s University, Atakum 55139, Samsun, Turkey. 
Secondly, Marx defines surplus value as profit of firm. Capitalists have two targets: maximum profit and minimum costs. Firms operate in markets in order to increase their profit. So, profits are their surplus for economy. Marx supposes that profit or surplus is belonging to workers to protect society from group conflicts.

Further, wages of labors were so low during 19th century. Labors obtained one dollar daily as compensation. Labors criticised that compensation policy and trade union emerged in European economy in 1825, England. Trade Unions are effective in USA economy by $10 \%$.

\section{Agency Theory: Struggle Between Professionals and Owners}

Industrial Revolution (IR) created new groups in society. They are owners, professionals, and labors. Farmers become labor, and the higher educated become professionals in large firms. Speciality of IR is factory system with mass production. Owners and professionals are separate in factory system, i.e., there are production manager, marketing manager, finance manager, logistics manager in firms, but they are not the owner of firm. That separation may generate agency theory in firm management. Because their interests may be different from each other that create conflicts between owner and professionals. There may be trust problem between owner and managers about firm's objectives.

In addition, there may be conflict between owner and labors. Labors demand more value and more profits from firm management. They want to become the owner of firm. Firms implemented low-wage policy during 19th Century. Further, working conditions were worse in firms in 19th century that leads to organizational psychology problem in organizations. Those two causes may have resulted in class struggle through 19th century: low-wage policy and worse working conditions.

Marx emphasizes class struggle in Communist Manifesto, in 1848, and he emphasized surplus value in Capital textbook, 1867. Agency Theory also mentions of class struggle in firm management between owner and professionals (principal, agent); therefore, agency theory is maybe related with Marx's ideology of class struggle, because he mentions of struggle between labor and owner in firm management.

\section{Economic Opinion's of Marx: Das Capital}

Marx considers that customer value of a product emerges from workforce efforts, labor. Workforce may upload value for products. So, qualifications of employees are necessary for competitivenes of a product and a firm.

Secondly, Marx discusses surplus value. It is profit. Aim of a firm is to obtain profit, or surplus value. Furthermore, Marx talks about compensation policy of firms in 1800s. Group conflict may appear with compensation policy, because capitalists have maximum profit and minimum costs targets. Marx argues that if state is owner of companies, workers would obtain more surplus value, and there would not be conflict between owner and the employees.

\section{Research Methodology}

Research methodology contains in-depth literature review based on IR chronology, socialism, and Karl Marx. Socialism and neo-marxist policy are related with 1st Industrial Revolution (Uysal, 2016a).

\section{Socialist Market Economy as a Neo-Marxist Policy}

Socialist economy has central planning and closed economy. Those may be conflicts of Soviet Union. State decides manufacturing and marketing decisions of firm in central planning, because companies are 
state-owned. And secondly, Soviet Block was closed economy. In SOEs public utility gains priority in firm management. However, profit orientation is the first in private organizations. Therefore, private organizations become more effective in firm management.

Socialist market economy assumes that state may become socialist but firms are to capitalists in markets. Thus, firms make decisions of their own marketing and production. For example, India may implement socialist market economy principles: central economy + capitalism. Indian authorities make plans for overall economy; and Indian firms decide its manufacturing and marketing operations.

\section{Discussion}

Karl Marx has three theories:

- Labor value theory,

- Group conflict theory,

- Scientific socialism.

Marx presented that labors upload value for products, and that affects product choice of customers. This is labor value theory, presented by David Ricardo, in 1816. Secondly, Industrial Revolution created new groups in society, and Marx disagrees with conflict between those new groups. Managers, owners, professionals, and workers are new groups of Industrial Revolution. Marx proposed that if state becomes owner of firms, there would not become conflict between owner and labors. Thirdly, Marx tends to scientific socialism which is explained by dialectic materialism notion.

\section{Impact of Hegel on Marx: Dialectics}

Marx has two opinions. They are dialectic materialism and communist manifesto. Marx obtained dialectic opinion from Hegel, and he added materialism dimension to dialectic. It is, dialectic materialism, scientific socialism. Scientific socialism tends to positivism in science.

Friedrich Hegel is philosopher in 1830s, who presented dialectic. There is theses-antitheses conflict in dialectic. In that era theses are industrial revolution and capitalism, and antitheses are socialism or communism. Marx is member of young Hegel clubs during his PhD era. He is impressed with opinions of Hegel. Marx added materialism dimension to dialectic.

Marx lived in France in 1840s. France was intellectual, cultural, and political centre of Europe in that era. He wrote communist manifesto in his French life. Marx presented manifesto in 1848. Maybe, French experience impressed Marx for writing Communist Manifesto.

Marx mentions for class struggle in 1848 of Communist Manifesto. Major supporters of Marx were Friedrich Engels. In that era earlier 1840, workers complained for wage policy of firms, because capitalists have enormous profit, and labors have low wage. That may have created class struggles.

Marx presented Manifesto for Communist League established in England. In 1840s French was center of socialism and England witnessed workers' protests against capitalists (owner of the firms, and owner of the profit).

\section{Conclusion}

Case of socialist economy is Central Planning. State does plans for production and marketing. According to socialist market economy principles, state may become socialist but firms may become capitalists. So, socialist economy may be applied through market economy. State implements central planning, but firms may implement their own production and marketing activity. 
Therefore, socialist market economy might be applied as neomarxist policy today.

This study disagrees with Marx's idea with two viewpoints:

1. There may not be group conflict in modern economy, because owners are entrepreneurs, and there should not become conflict between entrepreneurs and labors.

2. Firms are technology oriented anymore. So, technology-value theory may exist in firm management. So, technology may affect product choice.

There are two perspectives existing in global economy history: agriculture economy, and industrial economy. Agriculture economy is based on mercantilism such as Silk Road trade. Industrial economy is based on factories, mass production, and marketing.

Marx has two important contributions for sciences:

- Communist manifesto, 1848;

- Capital textbooks, 1867.

To conclude, Karl Marx has two academic developments: communist manifesto, 1848, and capital textbook, 1867. He searches for capitalism, and its production system.

\section{References}

Uysal, G. (2016a). Socialist market economy: Is it neomarxist policy? 19th Eurasia Business and Economics Conference, Istanbul Technical University, Istanbul, 26-28 May.

Uysal, G. (2016b). Marx and theory: Socialist market economy. 16th International Business and Management Conference, Doğu Akdeniz Araştırma Merkezi, Istanbul, 1-2 July. 